\title{
From Biopolitics to Biopoetics: a Hypothesis on the Relationship between Life and Writing
}

Julieta Yelin

Instituto de Estudios Críticos en Humanidades, CONICET-UNR

Follow this and additional works at: https://docs.lib.purdue.edu/clcweb

Part of the Arts and Humanities Commons

Dedicated to the dissemination of scholarly and professional information, Purdue University Press selects, develops, and distributes quality resources in several key subject areas for which its parent university is famous, including business, technology, health, veterinary medicine, and other selected disciplines in the humanities and sciences.

CLCWeb: Comparative Literature and Culture, the peer-reviewed, full-text, and open-access learned journal in the humanities and social sciences, publishes new scholarship following tenets of the discipline of comparative literature and the field of cultural studies designated as "comparative cultural studies." Publications in the journal are indexed in the Annual Bibliography of English Language and Literature (Chadwyck-Healey), the Arts and Humanities Citation Index (Thomson Reuters ISI), the Humanities Index (Wilson), Humanities International Complete (EBSCO), the International Bibliography of the Modern Language Association of America, and Scopus (Elsevier). The journal is affiliated with the Purdue University Press monograph series of Books in Comparative Cultural Studies. Contact: <clcweb@purdue.edu>

\section{Recommended Citation}

Yelin, Julieta. "From Biopolitics to Biopoetics: a Hypothesis on the Relationship between Life and Writing." CLCWeb: Comparative Literature and Culture 20.4 (2018): <https://doi.org/10.7771/1481-4374.3365>

This text has been double-blind peer reviewed by $2+1$ experts in the field.

The above text, published by Purdue University Press @Purdue University, has been downloaded 173 times as of $11 /$ $07 / 19$.

This document has been made available through Purdue e-Pubs, a service of the Purdue University Libraries. Please contact epubs@purdue.edu for additional information.

This is an Open Access journal. This means that it uses a funding model that does not charge readers or their institutions for access. Readers may freely read, download, copy, distribute, print, search, or link to the full texts of articles. This journal is covered under the CC BY-NC-ND license. 


\title{
PURDUE
}

UNIVERSITY PRESS <http://www.thepress.purdue.edu>

\section{CLCWeb: Comparative Literature and Culture}

ISSN 1481-4374 <http://docs.lib.purdue.edu/clcweb> Purdue University Press @Purdue University

CLCWeb: Comparative Literature and Culture, the peer-reviewed, full-text, and open-access learned journal in the humanities and social sciences, publishes new scholarship following tenets of the discipline of comparative literature and the field of cultural studies designated as "comparative cultural studies." In addition to the publication of articles, the journal publishes review articles of scholarly books and publishes research material in its Library Series. Publications in the journal are indexed in the Annual Bibliography of English Language and Literature (ChadwyckHealey), the Arts and Humanities Citation Index (Thomson Reuters ISI), the Humanities Index (Wilson), Humanities International Complete (EBSCO), the International Bibliography of the Modern Language Association of America, and Scopus (Elsevier). The journal is affiliated with the Purdue University Press monograph series of Books in Comparative Cultural Studies. Contact: <clcweb@purdue.edu>

\section{Volume 20 Issue 4 (December 2018) Article 5 Julieta Yelin,}

"From Biopolitics to Biopoetics: A hypothesis on the relationship between life and writing" <http://docs.lib.purdue.edu/clcweb/vol20/iss4/5>

\author{
Contents of CLCWeb: Comparative Literature and Culture 20.4 (2018) \\ Special Issue Processes of Subjectivation: Biopolitics Politics of Literature. Ed. Azucena G. Blanco \\ < http://docs.lib.purdue.edu/clcweb/vol20/iss4/>
}

Abstract: The objective of this article is to examine the theoretical potential of the dialogues between literary critique and biopolitical thought, with an analysis centered on a reconsideration of the concept of interpretation. In order to accomplish this, we analyze the shift in Michel Foucault's thought around the beginning of the 1970s, a time during which the notion of life took prominence over the study of literature as a specific discipline. From this transformation, a particular way of approaching both literary and, generally speaking, artistic creations can be derived that would give rise to a biopoetics perspective. 


\section{Julieta YELIN}

\section{From Biopolitics to Biopoetics: A Hypothesis on the Relationship between Life and Writing}

I can't help but dream about a kind of criticism that would try not to judge but to bring an oeuvre, a book, a sentence, an idea to life; it would light fires, watch the grass grow, listen to the wind, and catch the sea foam in the breeze and scatter it. It would multiply not judgments but signs of existence; it would summon them, drag them from their sleep. Perhaps it would invent them sometimes-all the better. All the better. Criticism that hands down sentences sends me to sleep; I'd like a criticism of scintillating leaps of the imagination. It would not be sovereign or dressed in red. It would bear the lightning of possible storms.

Michel Foucault ("On the Genealogy of Ethics" 323)

Since its birth in the mid-seventies, biopolitical theory has permeated the field of literary studies. In recent years, however, the dialogue between both areas has intensified due to the expansion and strengthening of transdisciplinary practices. Currently, there are numerous interventions in which theorists and critics reflect on the nuances that the bond between literature and life acquires; its textual configuration forms in the biography and in the so-called "writings on the self", and also in fictional writing in which the living being takes center stage, along with its philosophical dilemmas and political effects. It seems necessary, in this context, to foster the creation of a specific space of discussion that contributes new focuses and conceptualizations. That is, a space which provides tools to approach the texts in which the notion of life and its trials and tribulations-how to tell it, explore it and transform itare at play. To do so, it seems necessary to drink from the fountain of Foucauldian thought, not only because of the inaugural character of his theorizations but also due to his ability to produce, in his work and that of his successors, a transversal thought in which the literary, philosophical and political spheres interact and fuel each other mutually. Over the course of this article, we set out to address this problematic field through the formulation of two methodological questions, and of the consequent development of a conjectural response: the hypothesis of biopoetics.

\section{A return to interpretation?}

\section{Animal creators}

In the brief prologue to the French edition of a recent compilation of Michel Foucault's conferences on literature (La grande étrangère. A propos de littérature), the critics Philippe Artières, Jean-François Bert, Mathieu Potte-Bonneville and Judith Revel place said interventions in the wider context of life and the work of the thinker. They ask why, after the sixties (from which most of the material collated in the volume originated), Foucault interrupts his dialogue with literature, or at least ceases it in a direct, specific and intense way. Indeed, towards the mid-seventies Foucault's thought takes a significant turn; not only abandoning the reading and analysis of literary texts, but also delving into the study of the emerging field of biopolitics, while starting to trace a history of the modes of subjectification.

In the entry "Art" from Diccionario Foucault, Judith Revel pauses precisely in this moment of transition in which the Foucauldian thought moves away from the literary field in order to be devoted to the political sphere. However, Revel points out a series of theoretical continuities that she considers to be relevant: firstly, the fact that the pair power dispositifs/strategies of resistance, which is fundamental in the analyses of the political character, is "strictly speaking...a copy of the discursive order/transgressive experiences of language pair" (97), which characterized the works of Foucault in the 1960s. Additionally, Revel highlights the fact that both cases deal with forces that neither exclude nor deny each other but rather, on the contrary, mutually feed each other: "a relationship of setting in order and of identification, on the one hand, and a practice of removal or rejection of this order, on the other, they are mutually constructed: power and liberty are not in face-on opposition, rather they interpenetrate and feed off each other reciprocally" (97). On the other hand, the abandonment of literature-and, more generally, of the sphere of discourse-as an object of research could be read and interpreted as equating the discursive elements with other types of power relations and, therefore, of 
resistance strategies: "The literary word, be it an obedient instrument, or a form or contest of academic knowledge, is no more than a possibility of experimentation, but it would have to be considered together with the use of bodies, the relationship with oneself and with others, and a certain amount of conflict, etc. As a consequence, in reality it does not disappear; it is just integrated as part of a wider field (97)."

Such integration of the literary object into a wider critical field, that is, the resolve to reflect on the relationship between writing and the body, has allowed us to concoct a field of study, which for the time being is entirely conjectural, that would go by the name of biopoetics. This field would offer a transdisciplinary reading perspective capable of interrogating and eventually conceptualizing literary thought on life. (It is fitting here to clarify that the notion of "biopoetics" we aim to outline shares no resemblance with the notion defined in the framework of English-speaking, particularly North American, literary studies; see Cooke and Turner. In that context, the concept refers to a branch of literary critique which is dedicated to the study of biological influences in the implementation and reception of the diverse artistic disciplines and, for this reason, is considered a sub-discipline of socio-biology and developmental psychology. As the development of our work will demonstrate, our notion moves away from, and even opposes, the hypotheses that support that discipline.)

If for Foucault biopolitics represents-albeit in general terms and despite the variations and nuances that can be found in the different contexts of its production-a reconfiguration of the relationship between life and politics, that is, the emergence of a regulatory system through which life and its mechanisms enter "into the realm of explicit calculations" of politics, transforming "Knowledge-power" into "an agent of transformation of human life" (Foucault "Right of Death and Power over Life" 143), biopoetics would allude to a redefinition of the link between life and literature that, contrary to biopolitics, would deregulate the conventional forms of discriminating and organizing the living being. In other words, biopoetics studies a specific kind of meeting with and resistance to biopower, which can be understood as a force which affects not only the ways of life of societies, but also its forms of representation and imagination. Undoubtedly, in our current critical horizon we recognize numerous debates on the scope of biopolitics as a machine for life-management, control of populations and production of individuated forms, but the grammar that governs fictions of life and critical discourses that imprint models of this very logic on literature has barely begun to be studied. Likewise, a new discourse is just starting to emerge, one that focuses on the writings challenging those forms of literary imagination and that takes a leap of faith into unknown territory instead of settling for recognizing what was already known-fictions as reproductive machines of the taxonomies of the living. If these critical practices have anything in common with their objects of study it is their faith in the autopoietic work, in the idea that creation, in relation to intimacy as much as to animality-we shall shortly return to this point - prevails as an inevitable dialogue with the unknown.

The work we envision as biopoetics, whether materialized in literary writings or in critiques, could be identified with what Foucault called "counter-conducts": forms of resistance to biopolitical regulation that guide the search for unique ways to lead one's life. The presence of such a force, which counteracts individuation processes through a nurturing and care of the self that is aimed at redefining the animal status of the human being, corresponds with the agenda of what Roberto Esposito called "affirmative biopolitics". Biopoetics remains, therefore, interconnected with an affirmative biopolitics, considering all artistic work as an exploration of the links between the human and the animal or, in other words, as an investigation of the living away from the classifications imposed by the anthropocentric discourses. It is an investigation based on the premise that the artist is not a subject that has been superimposed onto its animal condition but rather an animal that is capable of creating, in spite of the process of humanization which is always disciplining - naming, individualizing, organizing hierarchies - their particular way of life.

There is an important point in Foucault's theory on the articulation between subjective constitution and creativity that, by inverting the causal relationship between them, clarifies what we have just exposed; indeed it is not a question of attributing the creative activity of a person to the type of relationship they maintain with themself but rather it is about linking the type of relationship the person maintains with themself to a creative activity (Foucault "On the Genealogy of Ethics" 262). The idea that subjectivity is the outcome of a constant and permanently incomplete process of self-constitution, and that this process involves contact with vital zones that have not been formatted by the human pattern, places reading and writing beyond the domain of esthetics - a discipline rooted in the idea that there are human values not subjected to the struggle for meaning, which is none other than the interpretative battle - while proposing the necessity of finding suitable questions with which to examine literary objects. Some of these, and perhaps those with most relevance for the current state of our field of study, are: how do we come up with critical tools that allow us to perceive the emergence of life in texts 
as a process, as a never-ending creation, envisioning therefore the transformative potential of literature? How do we counteract the disciplinary habit that makes us go down the same roads again and again? How, in short, do we convert our critical practice into a work of creation? And on the other hand, what type of relationships can be established between literary texts and the constrictions of the biopower, preventing us form falling into mimetic explanations - writing as an affirmation or resistance to these regulations? Above all, how do they translate to the poetics of life? More specifically; how do they impregnate the imaginaries produced by fictions, and what traces do they leave in critical discourses? These questions are centered on the problem of interpretation; though it fell out of favor several decades ago, this category re-emerges yet stronger in the discourse whenever artistic practices are thought of in their critical facet.

\section{A politics of culture}

In the prologue to Foucault's book Nietzsche, Freud, Marx, Eduardo Grüner defends an adherence to some of the fundamental presuppositions in Susan Sontag's famous essay "Against Interpretation," an antihermeneutical manifesto very much of a piece with theoretical trends of its composition in the 1960 s. Grüner believes that, after more than two decades, and especially considering (all) the texts/works that Foucault has published since, that formalist enthusiasm prevented a good part of criticism from thinking about a crucial aspect of interpretation: that it is not possible to separate it from the "source" texts, to clean them and prepare them for the enjoyment-sensitive, erotic as Sontag would say-of its formal construction.

Grüner highlights something which, though evident, has been considered very little in analyses of reception. Like Sontag, he takes Franz Kafka as a paradigmatic example and draws attention to the fact that these readings, when effective, are not restricted to translating a series of content, simplifying complexities through the tool of explanation, but they are rather incorporated into the work by gravitating around their context and, in this way, they go on to integrate the collection of symbolic or imaginary representations that constitute our culture. For any culture that has appreciated his work, Kafka cannot be detached from any of the interpretations-symbolic, historical, and psychoanalyticalthat adhere to him and which, at the same time, make him an interpreter of the society that reads him. Therefore, Grüner maintains, with Foucault, that esthetics is inseparable from ethics and politics, "in the precise sense of a cultural Ethos that is (consciously or not) inscribed in the work, and which the interpretations from the work form a part of, and also in the sense of a politicity by means of which the interpretation affects the conception a society has of the self" (2). Perhaps it could be added that this type of focus as a last resort tends to deconstruct the specific field of esthetics, or at least, to question its timeless and universal validity.

The defense of interpretation sketched by Grüner in the prologue to Foucault's text attempts to reconstruct the links between artistic works and social practices, evidently not in the usual explicatory sense, but rather by granting this bond a political foundation, with all of the nuances and complexities it implies. The concept of interpretation that Sontag battled against dramatically had its powers reduced, becoming restricted to the spheres of religion, pedagogy or any other method of textual domestication. The notion of interpretation that is deduced from Foucauldian work can be understood, in contrast, as the intervention in a symbolic battlefield from which it is impossible to remove oneself. This marginalization is an unattainable ideal, an underhanded and conservative strategy of intervention. With the policies of interpretation, Grüner argues, we see the same occurrence as with plain politics: we either do it ourselves, or we resign ourselves to tolerating what others do (2).

The shift towards biopolitics in Foucault's thought, linked to his increasing interest in social praxis and, in a strictly theoretical dimension, to the abandonment of the "outside" as a category of thought (Pelbart), finds a crucial methodological foundation in the notion of interpretation to which Grüner alludes. Interpretation, therefore, would involve modifying texts (from within) in order to produce new imaginaries and new symbolic systems which attribute meaning to the social practices, understanding that in Foucault's thought artistic production represents, inseparably, a gesture of creation and the fixing of forms of subjection or of mechanisms of power/knowledge. Therefore, once the idea of, "subversive omnipotence of certain artistic gestures-or of a kind of radical exteriority, absolute outsideness of the litterateurs' transgressive word" (Revel 31), has been abandoned, it is possible to reconsider literature as a process of creation in the framework of an abundant economy of knowledge, representations and codes which structure our relationship with the world. The transforming action must not be considered, as such, as an objective of interpretation but rather as its own condition of possibility: it is possible to keep interpreting because reality is transformable, and not the other way round. 
In light of these ideas, the proposal for an interpretive biopoetics focus is articulated coherently with the development of the latest Foucauldian thought. By this we mean, a focus that approaches critical and fictional texts in which the regimes of truth-to which the notion of life is subject-are resisted and questioned. In this sense, Biopoetics represents the conscious or unconscious strategies of resistance to the knowledge that a society has about life. To begin with, they challenge their title, changing it for the expression "forms of life": forms of subjectification that confront or evade the patterns imposed by biopower. Therefore, it seems relevant that the notion of biopoetics houses both the practice of critical reading and that of fictional and poetic writing, with the understanding that all forms of freedom and the capacity for transformation imply a political-biopolitical intervention in meaning that can be carried out from both sides of the word.

In the framework which, following Nietzsche, Vanessa Lemm has called "politics of culture", the objective of biopoetics would be to cultivate forms of sociability from practices based on self-care: that is, on the cultural liberation of animal life. Lemm reinforces the idea that cultural liberation of animal life by no means assumes the existence of "a human nature which has been alienated, repressed or denied through historical, economical and social processes and therefore needs to be liberated in order to reconcile the human being with its lost animal nature" (Lemm "The Biological Threshold of Modern Politics" 733). On the contrary, what Nietzsche considers "cultural liberation"-and what Foucault conceptualizes as "resistance" or "counter-conduct"-implies the rejection of the idea that the human being has its own nature: "When Nietzsche prescribes a 'return to nature' as a 'cure for civilization' he means a 'cure' from the belief that the human being always already has a fixed and stable nature, for example, a moral or a rational nature" (733).

Foucault's reflections on subjectivity as a process of self-constitution and his idea that the only way of resisting the disciplinary violence of biopower is through self-care, that is, by nurturing the existence of the human being as both a living animal and a creator, are coherently linked with the aforementioned Nietzschean premise of subjectification as a continual movement of opening up to the animal otherness. This opening is a way of nurturing creativity, which is the condition that makes culture possible; therefore, culture and creativity are, according to both Nietzsche and Foucault, intimately linked to animality, because it offers not only a new way of considering our relationship with memory-producer of individual and collective identity-but also an alternative paradigm of truth (Lemm La filosofía animal de Nietzsche 272). Biopoetics as a discipline of knowledge takes on, in this way, the perspective of a politics of culture (Lemm), on the understanding that human life is inseparable from other life forms and that all of its potential is born from this relationship. In effect, without the antagonism that is generated between different forms of life, it is impossible to generate one's own life form. The politics of culture is, in this sense, an elemental form of creation and resistance.

This antagonism forms a nucleus that is crucial for understanding the purpose of biopoetics, which adopts the two fundamental tasks that Nietzsche assigns to culture. On one hand, there is the critical task consisting in demonstrating that the processes of civilization-rationalization, moralization, disciplining, in short, the humanization of the human being-acts through violent techniques of eradication or denial of the human being's animality. The objective is to make the symbolic mechanisms and procedures of representation, through which life is domesticated, visible. On the other hand, there is an affirmative or creative task, which consists in generating ways of life and thought that participate in animality instead of being detached from it. From the perspective of biopoetics, this second task corresponds fundamentally to literature, while the first would be reserved for literary critique.

A biopolitics of interpretation must revise, consequently, the whole system of conventions that sustain the relationship between the writer and the text, the text and the reader, the writer and the reader. It must do so by understanding not only that those who write and read are living animals and, therefore that their relationship with texts is influenced by emotional, sexual and irrational impulses, but also assuming that the creations cannot continue to be submitted to evaluations deriving from the theoretical body of esthetics or anthropocentric philosophy which idealize and domesticate meaning. On the understanding also that it is necessary to intervene, creating categories and methodologies of analyses aimed at de-totalizing the regimes of truth which are institutionalized by cultures, and to retotalize them in opposition to other interpretive strategies. In other words, we need strategies of biopoetics that also reject the regimes of economic and symbolic exploitation of biopolitics through the sensitive search for what exceeds them, for what does not fit due to multiple or unfinished character; in short a search for whatever challenges the established order of words and things.

\section{A literary thought on life?}

This strange institution 
So how can the legacy of the "latest Foucault" be made to work in favor of literary theory? This question concerns not only the transversal potential of said thought but also, very provocatively, the value and impression that political and philosophical reflection have had on our disciplinary field over the last decades. Clearly, for us-I mean, for those interested in literary thought, in the particular way in which fictions, produced in the framework, and also in the margins, of "this strange institution called literature" (Derrida "This Strange Institution" 33-75) create meaning-all literary expression is, at the same time, political and philosophical expression. Or rather, expression that can only be political and philosophical, inasmuch as its main task - voluntary or involuntary-is to touch and modify the boundaries of meaning, to explore its fissures. How, then, can we designate the transformative potential of literature, its capacity to disrupt all values-even those accepted as its own-and its capacity to blur the boundaries that define our perception of the world: what is human and animal, individual and collective, rational and irrational, real and imaginary, masculine and feminine, alive and dead?

In an interview at the end of the eighties, Jacques Derrida characterized literature precisely as this field which is capable of going beyond itself, as the facilitating space not only of an instituted fiction but of a fictional institution. Foucault himself, some years before, in a conversation with Shigehiko Hasumi, reflected on his growing interest in the writings that are produced on the margins of the institution, be they "outward"-everyday anonymous language-or in the interstices of the disciplines. In this instance, he referred to a series of writers impossible to characterize as philosophers or litterateurs in whose works, he stated, "it is the thought that is about to speak, the thought, in a way, always toing and froing from language, breaking away from language." Foucault recognizes that, for a long time, he was interested in this "extremely curious relationship of links, reciprocal improvements, connections and mismatches between thought and discourse [...]" (Foucault "Right of Death and Power over Life" 152).

Having said that, it is necessary to clarify that by "literature" we do not allude to a specific form of representation nor estheticization of the living-where the purpose is to set apart what is literary from the discursive and evaluative horizon of esthetics-but rather to the creation of another way of thought. A way that is capable, due to its self-reflexive character, of establishing an effective and productive dialogue with both political and philosophical discourses. Biopoetics would be presented, therefore, as an area of reflection on this capacity of institutional and disciplinary surpassing that lives in the literary thought of life. It shares, in this aspect, a concern that crosses over with literary theory from the last decades, though with the particularity of establishing an explicit link with philosophical-political thought on life; that is, with the idea that what is human is a historicizable creation and that its definition of "subject of language" does not imply the verification of a differential property but rather the recognition of a border, that which Giorgio Agamben has termed the "experimentum linguae": the certainty that there is language and that we cannot represent it.

As we have contended thus far, biopoetics would function as a noun. That is to say, it would eventually fulfill a similar role to that of biopolitics-which integrates and brings into dialogue the ontological and political thought of life-but also include within itself the particularity of literary expression to approach reality. But the notion of biopoetics would also operate as an adjective, that is, as a quality of a creative practice, whether it be in the production of fiction or of something like the essay. It would be possible to speak, in this sense, of biopoetic narratives, biopoetic procedures or of a biopoetic theory and a biopoetic critique. All of these formulas share a special interest in the relationship between life, body and writing which is decisive in the constitution of a non-anthropocentric study perspective. Literature, from this point of view, reads the world with the eyes of the body - the formula has been adopted by Esposito from The New Science by Giambattista Vico (Esposito Las personas y las cosas 111). With this formula, Esposito exposes a way of approaching what is real, which is a philosophical elaboration of a suspicion regarding reason as the privileged form of knowledge, and a distancing from the idea of what is one's own in favor of what is common, or shared. Biopoetics proposes, therefore, a viewpoint which, on the one hand shifts the center of analysis from the human to the vitalunderstanding the latter as a reality that also concerns the physical and material dimension of existence-and, on the other hand, that understands this corporal materiality as an area of dispute subject to continual recreations; a reality that cannot be considered as a mere thing yet can neither be identified completely with the person, and which is, at the same time, common, shared, and is the condition that makes the emergence of singular life forms possible. This transindividual body, charged with ambivalence, requires, as Esposito points out, a philosophical and legal redefinition; it could be deduced, that it also demands the intervention of literary expression: Why should literary writing, in all its manifestations, not participate in this conceptual exploration?

It proves, therefore, stimulating to think of the adjective form of "biopoetics" as an attribute not only of critical thought but also as a form of intervention of fictions. In this sense, it could be considered that 
in the last decades, parallel to the development of European biopolitical thought, narratives in which the notion of life is besieged, problematized, transmuted are being written (I am thinking of Latin America, but this is surely a hypothesis that can be tested in other latitudes). Let us take as an example the experiments of Mexicans Mario Bellatin and Daniela Tarazona, the Chilean Diamela Eltit, the Brazilian Nuno Ramos, and the Argentineans César Aira, Iosi Havilio or Ariana Harwicz, to name a mere few. In their texts, the body-biological and social-is converted into a zone of experimentation, subjection and resistance, and the notion of life is put under strain, for example through the work of identity deconstruction in the creation of characters or the questioning of the distinction between autobiographical and autofictional writing. Literature is converted, therefore, into a machine that considers the living being as a continuum that shifts under language and that resists, amongst other aspects of biopower, the classifying violence of the discourse of the species.

\section{Biopoeticize}

That being said, used as a noun or adjective, there are some primordial methodological questions concerning biopoetics: How, or with which tools, to approach its corpus? How to rigorously exercise its renowned transdisciplinarity? What is the critical frame of mind that a complex and evasive object imposes? It would be desirable, for a start, to link this new sphere of reflection to curiosity, in the strict sense that Foucault has attributed to the word, with a fine-tuned focus on its "care" root and the regard that must be taken of what exists and what might exist (Estética, ética y hermenéutica 222). This observation gives rise to the consideration of the virtual character of the living being, and the double stimulus that this feature presents to the curious reader or writer: the possible emergence of the still unknown and the uncertain character of this existence. Specifically concerning "literary expression", such stimuli would refer to a special attention to the potentiality of writing; for the writer, the perception that they work with a living material - which is not equal to itself - which is home to the unthinkable as the flipside of the thought. For the critic, these stimuli would refer to the relevance of what is alive in the texts, the respect to its precariousness, the will to apprehend, knowing that it is impossible, the infinite nuances of the living being. In short, biopoetics is to be understood as a type of curious relationship with language. An active, inquisitive, but also affirmative way of understanding the interpretation - of the world and of the texts.

In an interview that Vanessa Lemm and Miguel Vatter conducted some years ago, Esposito reflected on the place of literature and of art in general in the process of conceptual transformation that arose from the close relationship between politics and biological life, as Foucault has identified and examined in the last stage of his production. In relation to this, Esposito maintains that it is not a question of an abrupt change of regime but rather a creation of new ties, of the exposure of questions which can no longer be answered with the old categories. Therefore, he states that is it necessary to create other instruments, to implement a different lexis and, in short, to generate a new horizon of thought. Faced with the question of whether it is possible to recognize this search in other practices and languages that diverge from the western philosophical tradition, Esposito affirmatively responds and alludes, by way of example, to the deconstruction of the concept of person that we see in the work of Franz Kafka, who he considers "a powerfully, tragically, biopolitical author". Joining an already prolific tradition of posthumanist philosophers that draw from Kafka's writings to consider questions that do not strictly belong to the field of literary studies, Esposito meticulously examines the ability that literature possesses to detect outdated ideas and to propose new forms. "Literature from the last century," Esposito writes, "since The Man Without Qualities by Robert Musil up until the latest North American novels from recent years, has been a significant contribution to this change in lexis, constituting one of its focal points. Art in general tends to be ahead of philosophy which, as the old Hegel would have certainly seen, always turns up later, like Minerva's owl" ("Biopolítica y filosofía"). Effectively, the question of impersonality as a force that partakes in the entire process of subjectification is insistently approached through modern literary writing; it is no wonder that many of the so-called "philosophers of life" turn to fictional texts in order to reflect on the topic, nor is it surprising that they find a rich source for ethical reflection in literary thought. This is precisely what Gilles Deleuze does when he evokes the dying figure from Our Mutual Friend by Charles Dickens in "Immanence: a life...", or in his essay on the devastating force of language in the formula, "I would prefer not to" in Bartleby the Scrivener ("Bartleby or the formula"), or Jacques Derrida, Felix Guattari, Deleuze himself, Agamben or Esposito in their diverse references to the work or Kafka.

If it is possible to affirm that philosophy comes afterwards, or rather, that literature can anticipate certain transformations through conceptual imagination, this must be connected to the capacity of the literary word to contemplate language, using language. Again and again, the literary philosophers we 
have mentioned pause to reflect on this; and this reflection seems to insistently indicate the decline of humanist metaphysics as a thought paradigm and the influx of theorization forms which are sensitive to games of power and knowledge. To biopoeticize is to think in terms of a life and not in terms of the life, to experiment with new life forms that, in turn, would collaborate in the construction of new political concepts through the generation of contrasts, resistances, conflicts, in a dialogue that affects both parties equally. Thus, there is no way of setting apart the forms of life from the forms of thought - in the same way as it is impossible to distinguish, from this same perspective, between language and experience. It is for this motive that literary thought constitutes an enormously rich conceptual source; by proposing forms of knowledge that surpass, as we have mentioned, the rational sphere, writing comes into direct contact with the sensitive, ambiguous and unstable nature of language. This contact also gives rise to the biopolitics of interpretation, a critical horizon from which literary expression is contemplated against the grain of the enduring evaluations of esthetics.

From these initial approaches to the notion of biopoetics, we can deduce the value and function required to accomplish Foucauldian thought in its constitution, in view of its capacity to articulate problems and tools through the creation of new objects and methods of approach and, fundamentally, through the introduction of time as a determining variable in conceptual analysis. Both of his reflections from the seventies on language and literature-which, as Azucena González Blanco clearly points out, productively negotiate with the different areas defined by his thought: epistemology, ontology, politics, ethics (2005-2007) - and those corresponding to the last stage of his production, contribute decisively to the configuration of a theoretical-critical field focused on investigating the literary mechanismsformal, symbolic, political, conceptual-of textual production of the living being, that is, on the literary creation of a non-anthropocentric thought on life.

Foucauldian thought allows us, in this way, not only to imagine a new field of study and a method of approach within it, but also to deal with the transformations suffered by the relationship between writing, subjectivity and truth. If we consider the two important hypotheses that governed this relationship from the modern "invention" of literature-the humanist vision, which conceptualizes literature as a reflex of the mentality and the emotion of an author, being materialized in the notion of "style", and the structuralist vision that removes the figure of the author from the game to establish the truth of the text-the idea of a perspective that incorporates Foucauldian contributions in relation to subjectivity, which include, as we have already pointed out, a renewed focus on the notion of life, proves stimulating. By introducing the "techniques of the self" to the analysis, we contemplate the possibility of understanding life not only as an area of experimentation and subjection of governmental techniques, but also as a space of resistance, a resistance that is of course blind, impersonal and by no means voluntarist, but a resistance in which the seedling of change can be observed, as the possibility that an affirmative biopolitics can, at least, fight its battle.

Finally, if biopolitical thought produced in the present day is oriented towards what Esposito imagined as an affirmative biopolitics, in which bios and zoe can, albeit in the realm of the imaginary, re-articulate themselves, in which body and mind, health and illness are impossible to distinguish, then we should not neglect the dialogue with biopoetic thought. This would have to define more clearly its interests, testing its hypotheses and characterizing the specific modalities of its utterances. Writers, following Kafka, are progressing on this path. Literary critique seems to have greater difficulties in detaching itself from the discursive pattern of humanism. If it makes the compromise to refrain from judging and sentencing-that is, if it finally abandons esthetics as fundamental horizon of thought-in order to, as Foucault has said, focus on listening to literary expression, and on "making a work, a book, a phrase, an idea exist", it would have to be reconciled with the invention, with the "imaginative glimmers" that, in short, are what produce the concepts, what re-create lexis, what make theory. In this way, it would take away-perhaps biopoetics has such luck - "the lightning of the possible storms" (Foucault "On the Genealogy of Ethics" 323).

\section{Works Cited}

AAVV. Preferiría no hacerlo. Bartleby el escribiente seguido de tres ensayos sobre Bartleby de Gilles Deleuze, Giorgio Agamben y José Luis Pardo (Bartleby the Scrivener, Followed by Three Essays on Bartleby by Gilles Deleuze, Giorgio Agamben and José Luis Pardo). Valencia: Pre-Textos, 2000.

Agamben, Giorgio. "Experimentum linguae". Infancia e historia. Ensayo sobre la destrucción de la experiencia (Infancy and History: The Destruction of Experience). Buenos Aires: Adriana Hidalgo, 2001. 207-219.

Cooke, Brett and Frederic Turner. Biopoetics. Evolutionary Explorations in the Arts. Paragon House, 1999.

Deleuze, Gilles. "La inmanencia: una vida..." (Immanence. A Life...). Giorgi, Gabriel y Fermín Rodríguez (comp.). Ensayos sobre biopolítica. Excesos de vida (Essays on Biopolitics. Excesses of Life). Buenos Aires: Paidós, 2007. 35-40. 
Deleuze, Gilles and Felix Guattari. Kafka. Pour une littérature mineur (Kafka: Toward a Minor Literature). Paris: Minuit, 1975

---. "1730. Devenir-intenso, devenir-animal, devenir-imperceptible..." (1730: Becoming-Intense, Becoming-Animal, Becoming-Imperceptible...). En: Mil mesetas. Capitalismo y esquizofrenia (A Thousand Plateaus. Capitalism and Schizophrenia). Valencia: Pre-textos, 1988. 239-315.

Derrida, Jacques. "Préjugés. Devant la loi" (Prejudices. Before the Law). AAVV. La faculté de juger (The Faculty of Judging). Paris: Minuit, 1985. 87-139.

---. "This Strange Institution Called Literature": An Interview with Jacques Derrida'. Attridge, Derek (Ed.). Acts of Literature. London and New York: Rouledge, 1992. 33-75.

Esposito, Roberto. "Biopolítica y Filosofía (Entrevistado por Vanessa Lemm y Miguel Vatter)" (Biopolitics and Philosophy (Interviewed by Vanessa Lemm and Miguel Vatter)). Revista de filosofía política v. 29, no 1 (2009): 133-141.

---. Las personas y las cosas (Persons and Things). Buenos Aires: Katz-Eudeba, 2016.

Foucault, Michel. "On the Genealogy of Ethics: An Overview of Work in Progress". Ethics: Subjectivity and Truth. The Essentials Works of Michel Foucault 1954-1984. Vol. 1 (Paul Rabinow ed.). New York: The New Press, 1997. 253280.

---. "Right of Death and Power over Life". The History of Sexuality, Vol. I. New York: Pantheon, 1978. $133-159$.

---. Estrategias de poder. Obras esenciales, volumen II (Power Strategies. Essential Works, II). Buenos Aires: Paidós, 1999a.

---. Estética ética y hermenéutica. Obras esenciales, volumen III (Estetics, Ethics and Hermeneutics. Essential Works, III). Buenos Aires: Paidós, 1999b.

---. Le grande étrangère. À propós de littérature (The Great Stranger: On Literature) Paris: EHESS, 2013.

González Blanco, Azucena. El logos doble (Una introducción al pensamiento estético-literario de Michel Foucault) (The Double Logos: An Introduction to Michel Foucault's Aesthetic-Literary Thinking). Universidad de Granada, 2005. Accesible en http://digibug.ugr.es/bitstream/10481/868/1/15891240.pdf

---. "Foucault y la teoría de la literatura" (Foucault and Literary Theory). Boletín 13/14 (2007): 1-12. Accesible en http://www.celarg.org/int/arch publi/gonzalez blanco13 14.pdf

Grüner, Eduardo. "Foucault: una política de la interpretación" (Foucault: A Politics of Interpretation). Topos y tropos (2004): 3. 1-9.

Lemm, Vanessa. La filosofía animal de Nietzsche. Cultura, política y animalidad del ser humano (The Animal Philosophy of Nietzsche. Culture, Politics and Animal Life of the Human Being). Santiago de Chile: Universidad Diego Portales, 2010.

---. "The Biological Threshold of Modern Politics. Nietzsche, Foucault and the Question of Animal Life". Siemens, Herman and Vasti Roodt (Eds.). Nietzsche, Power and Politics: Rethinking Nietzsche's Legacy for Political Thought. Berlin and New York: Walter de Gruyter, 2013. 719-739.

Pelbart, Peter Pál. "O lugar da literatura na obra de Foucault" (The Place of Literature in Foucault's Work). Cult 134 (2009): s/n. Accesible en http://revistacult.uol.com.br/home/2010/03/fala-dos-confins.

Revel, Judith . Diccionario Foucault (Foucault Dictionary). Buenos Aires: Nueva Visión, 2009.

Author's profile: Julieta Yelin is a PhD in Humanities (National University of Rosario) and Adjunct Researcher of the National Council of Scientific and Technical Research of Argentina (CONICET). She is director of the Bulletin of the Center of Studies of Literary Theory and Criticism, and member of the Editorial Board of Badebec magazine (www.badebec.org). She has published La letra salvaje. Ensayos sobre literatura y animalidad (The wild letter. Essays on Literature and Animality) (Beatriz Viterbo Editora, 2015) and, in collaboration with Elisa Martínez Salazar, Kafka en las dos orillas. Antología de la recepción crítica española e hispanoamericana (Kafka on the Two Shores. Anthology of Spanish and Hispanic American Critical Reception) (Prensas de la Universidad de Zaragoza, 2013).

E-mail: julietayelin@conicet.gov.ar 